\title{
Adrenal Incidentaloma: Imaging Approach and Differential Diagnosis
}

부신우연종: 영상의학적 접근과 감별진단

\section{Myoung Seok Lee, MD* (D), Min Hoan Moon, MD D , Chang Kyu Sung, MD (D)}

Department of Radiology, Seoul Metropolitan Government-Seoul National University Boramae Medical Center, Seoul, Korea

Adrenal incidentaloma refers to adrenal masses that are accidentally found on imaging performed for other reasons, without clinical symptoms of adrenal disease. Generally, adrenal masses measuring less than $1 \mathrm{~cm}$ are not considered adrenal incidentalomas. The purpose of radiologic examination in evaluating non-functioning adrenal incidentalomas is to distinguish between benign and malignant masses to establish the treatment plan. In this review, based on previously published research and recommendations, we describe the radiologic approach for adrenal incidentaloma and describe the imaging findings of representative diseases.

Index terms Adrenal Incidentaloma; Adrenal Gland; Adrenocortical Adenoma

\section{서론: 부신우연종의 빈도와 임상적 의의}

부신우연종(adrenal incidentaloma)은 부신 질환을 의심할 만한 임상증상 없이, 다른 이 유로 시행한 영상검사에서 우연히 발견된 $1 \mathrm{~cm}$ 이상의 부신 종괴로, 복부 $\mathrm{CT}$ 를 촬영한 환자 의 4 5\%에서 부신 종괴가 발견되며, 유병률은 연령에 따라 증가하여 20대에서는 $0.5 \%$ 이지 만 70대에서는 7\% 정도를 보인다 $(1,2)$. 일반적으로 $1 \mathrm{~cm}$ 미만의 종괴는 부신우연종으로 간 주하지 않는데, 그 이유는 $1 \mathrm{~cm}$ 미만의 부신 종괴에서는 진단능을 향상시킬 수 있는 증명된 영상의학적 방법이 없기 때문이고, 따라서 대부분의 영상의학자들의 경우 $1 \mathrm{~cm}$ 미만의 부 신 종괴에 대하여 추가적 영상검사를 권유하지 않는다(3).

부신우연종의 80\%는 부신선종(adrenal adenoma), 특히 비기능성 부신선종(non-functioning adrenal adenoma)이므로(4, 5), 부신우연종의 영상의학적 접근에서 중요한 것은 부신선종을 진단하는 것이다. 그러나 암 환자 코호트에서 발견된 부신우연종의 50 75\%가 전이암이라는 보고가 있고 $(6,7)$, 일부 기능성 부신종양이 우연종으로 발견될 수 있으므로 환자 병력, 증상, 생화학적 검사를 포함한 혈액 및 체액검사 결과, 그리고 영상검사 결과 모
Received October 8, 2019

Revised November 19, 2019

Accepted November 25, 2019

*Corresponding author Myoung Seok Lee, MD Department of Radiology, Seoul Metropolitan GovernmentSeoul National University Boramae Medical Center, 20 Boramae-ro 5-gil, Dongjak-gu, Seoul 07061, Korea.

Tel 82-2-870-2542

Fax 82-2-870-3539

E-mail achieva1004@gmail.com

This is an Open Access article distributed under the terms of the Creative Commons Attribution Non-Commercial License (https://creativecommons.org/ licenses/by-nc/4.0) which permits unrestricted non-commercial use, distribution, and reproduction in any medium, provided the original work is properly cited.

\section{ORCID iDs}

Myoung Seok Lee (1) https://

orcid.org/0000-0001-5285-4874

Min Hoan Moon (D)

https://

orcid.org/0000-0003-2448-2895

Chang Kyu Sung (D)

https://

orcid.org/0000-0003-4922-5107 
두를 종합하여 정확한 진단을 내리는 것이 추후 치료 및 평가에 중요하다.

부신우연종은 내분비 기능이 있는 종괴(functioning adrenal incidentaloma)와 없는 종괴 (non-functioning adrenal incidentaloma)로 구분한다. 내분비 기능이 있는 종괴의 감별진단은 환자의 증상과 혈액 및 체액검사 결과에 근거하여 이루어지는 경우가 많으며, 영상검사의 역할은 감별진단의 보조적 역할과 동시에 종괴의 개수 및 위치를 파악하여 추후 이루어지는 수술적 절제 에 해부학적 정보를 제공하는 것이다. 내분비 기능이 없는 종괴의 경우, 영상검사는 진단 및 이에 따른 치료 방침 결정에 중심 역할을 담당하게 된다. 또한, 종괴의 기능성 유무와 별개로, 부신우연 종의 양성 및 악성 여부를 판단하여야 하며, 영상의학적 검사는 이에 대한 중요한 단서를 제공하 게 된다.

따라서 부신우연종을 접하였을 때, 영상의학적으로 어떤 분석을 해야 하며 어떤 추가 검사를 권 고해야 하는지를 숙지하는 것은 영상의학과 의사에게 매우 중요하다. 이에 2010년 미국방사선학 회(American College of Radiology; 이하 ACR)에서는 부신우연종의 영상의학적 접근에 대한 백 서를 발간하였고, 2017년에 두 번째 개정판을 발표하였다(8). 본 종설에서는, 상술한 ACR 권고안 및 타 연구를 근거로 하여 부신우연종의 영상의학적 접근 방법을 기술하고, 대표적인 종괴의 영상 소견을 기술하고자 한다.

\section{부신의 영상검사: 부신우연종을 중심으로}

부신우연종의 감별진단에서 가장 중요한 점은 부신선종을 감별진단하는 것이다. 따라서 본 단 락에서는 부신선종의 진단을 위한 영상 기법의 이용에 대해 기술하고자 한다. 대부분의 부신선종 은 영상의학적 방법으로 진단이 가능하므로, 부신의 영상 진단을 통하여 불필요한 조직 검사나 수 술을 방지할 수 있게 되어 이로 인한 이환율(modbidity)과 의료비용을 낮출 수 있다(9, 10). 따라 서 부신 영상 기법의 종류와 특성, 한계점을 숙지하는 것은 올바른 병변 특성화(characterization) 및 감별진단에 중요하다.

\section{조영증강 전 CT (Unenhanced CT)}

조영증강 전 CT는 부신선종, 특히 지방풍부 부신선종(lipid-rich adrenal adenoma)을 특성화 하는 데 매우 효과적인 영상 기법이다. 부신선종은 조직학적으로 세포질 내부에 풍부한 지방을 가 지고 있으며, 이러한 세포질 내 지방 성분으로 인해 부신선종은 조영증강 전 CT에서 낮은 감쇠계 수(Hounsfiend unit; 이하 HU)를 보이며, 세포질 내 지방성분이 증가할수록 병변의 감쇠계수는 낮아진다(Fig. 1) (11). 조영증강 전 CT 감쇠계수 $10 \mathrm{HU}$ 를 기준으로 삼아 그 이하의 감쇠계수를 보 이는 종괴는 지방풍부 부신선종으로 진단할 수 있고, 이의 특이도는 $98 \%$ 에 이른다 $(9,12,13)$. 그 러나, 병변 내부 또는 주변에 $10 \mathrm{HU}$ 이상의 고음영 병변이 보이면 조영증강 CT를 시행하여야 하 며, 병변이 조영증강 전 CT에서 비균질한 감쇠를 보일 경우 충돌종양(collision tumor)과 같이 선 종이 아닌 다른 병변이 동반되었을 가능성을 염두에 두어야 한다 $(14,15)$. 
Fig. 1. Lipid-rich adenoma in the left adrenal gland of a 31-year-old man.

A, B. Unenhanced CT shows a 1.3-cm well-defined nodule in the left adrenal gland ( , arrow), with an attenuation value of $7 \mathrm{HU}$ (under $10 \mathrm{HU}$ ) (B).

$\mathrm{HU}=$ Hounsfield unit, SD = standard deviation
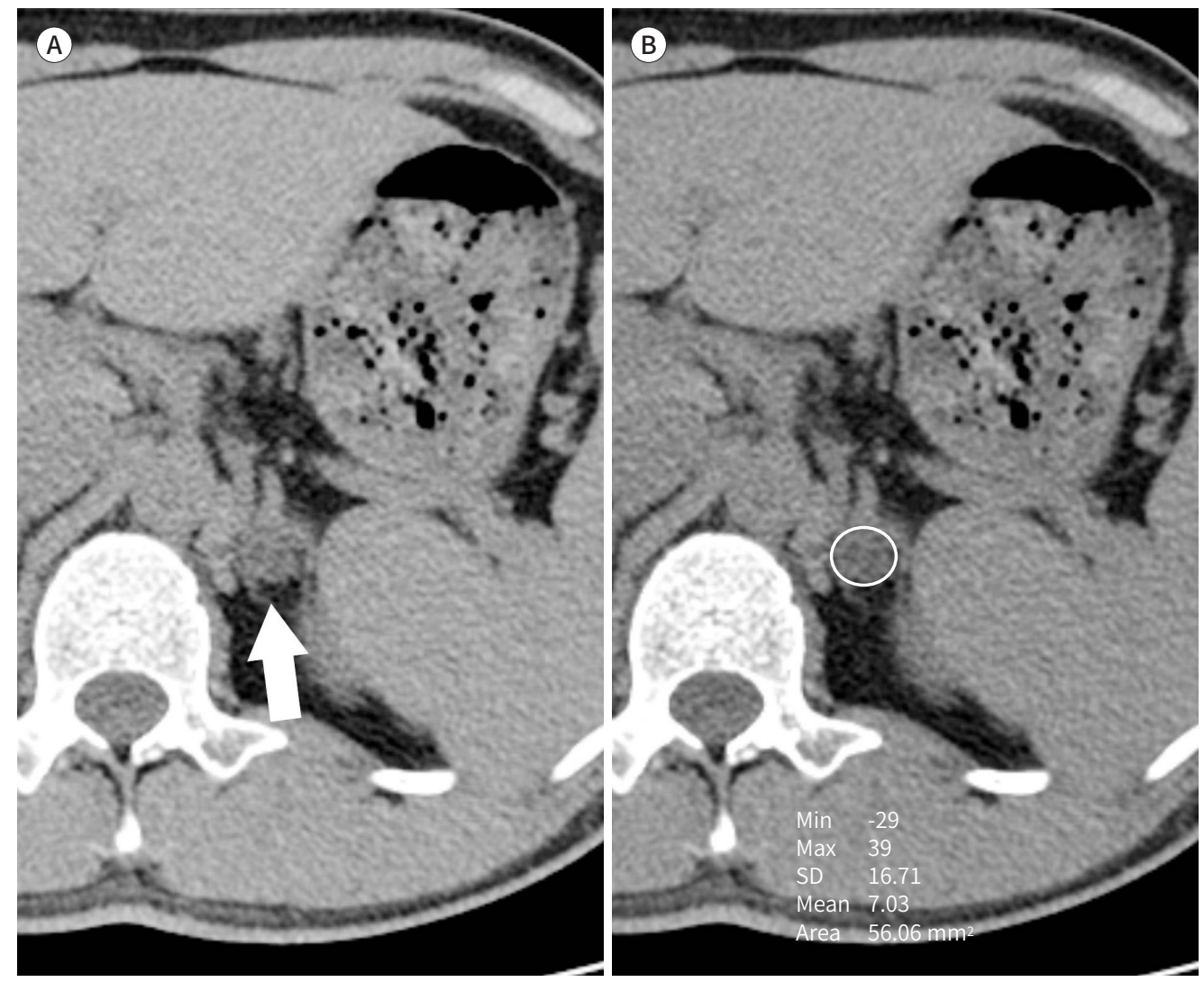

\section{화학변위 MR 영상(Chemical Shift MR Imaging)}

화학적 이동(chemical shift)은 분자의 구조에 따라 수소원자핵 주위의 환경이 달라 발생하는 공명주파수의 미세한 차이를 말하며, 자장의 세기에 비례하여 증가한다. 지방 속의 수소원자는 물 의 수소원자보다 $1.5 \mathrm{~T}$ 에서는 $220 \mathrm{~Hz}, 3 \mathrm{~T}$ 에서는 $440 \mathrm{~Hz}$ 만큼 낮은 공명주파수를 갖는다(15). 따라 서 $1.5 \mathrm{~T}$ 기준으로 지방의 수소원자와 물의 수소원자의 위상이 합쳐지는 동위상(in-phase)과 위상 이 $180^{\circ}$ 차이 나게 되는 탈위상(opposed phase)이 $2.2 \mathrm{msec}$ 마다 반복되며, 이에 맞추어 경사에코 자장을 사용하여 얻은 영상이 화학변위 $\mathrm{MR}$ 영상이다.

대부분의 부신선종은 정성적으로 동위상 영상보다 탈위상 영상에서 신호강도가 떨어지는(signal drop) 소견을 육안 관찰하는 것으로 진단이 가능하며, 정량적 측정과 비슷한 진단능을 보임이 보고되어 있다(16-18). 그러나 조영증강 전 CT에서 $10 \mathrm{HU}$ 이상의 감쇠계수를 보이는 부신선종의 경우, 정량적 측정이 정성적 방법보다 더 정확함이 보고되어 있다(19). $20 \mathrm{HU}$ 이하를 보이는 부신 선종의 진단에 있어 화학변위 MR 영상의 민감도는 $100 \%$ 에 이르며, 따라서 조영증강 전 CT에서 $10 ~ 20 \mathrm{HU}$ 의 감쇠계수를 보이는 경우 화학변위 MR 영상 단독으로 부신선종을 진단할 수 있다

(Fig. 2) (20, 21).

화학변위 MR 영상의 정량적 측정은 신호강도비(signal intensity ratio)의 측정을 의미하며, 대 
Fig. 2. Chemical shift imaging.

A-C. On unenhanced CT (A) of a 64-year-old man with gastric cancer, a solid mass (arrows) measuring 2.2 $\mathrm{cm}$ is observed in the right adrenal gland. The attenuation value is $18.5 \mathrm{HU}$, which makes it difficult to differentiate between adrenal adenoma and adrenal metastasis. The signal intensity of the right adrenal mass is visually reduced in the opposed-phase image (B) compared to the in-phase image (C). In the quantitative analysis, the adrenal-to-spleen ratio was 0.20 , and the signal intensity index was $81.0 \%$. Therefore, the right adrenal nodule could be diagnosed as adrenal adenoma rather than adrenal metastasis.

$\mathrm{HU}=$ Hounsfield unit, $\mathrm{SD}=$ standard deviation
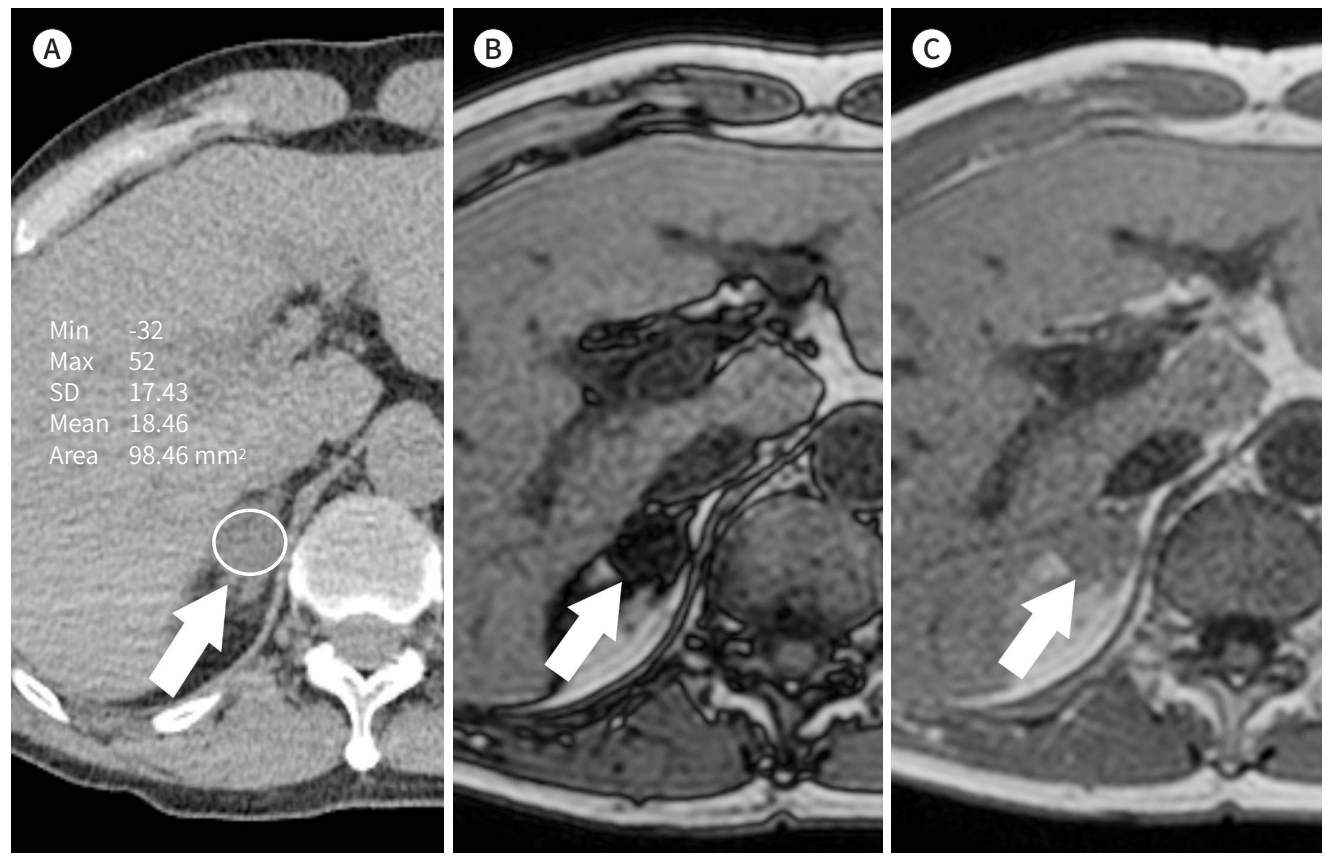

표적인 지표로는 adrenal to spleen ratio (이하 ASR)와 signal intensity index (이하 SII)가 있다. 각각의 계산 공식은 다음과 같다.

$$
\begin{aligned}
& \mathrm{ASR}=\left(\mathrm{A}_{\mathrm{OP}} / \mathrm{S}_{\mathrm{OP}}\right) /\left(\mathrm{A}_{\mathrm{IP}} / \mathrm{S}_{\mathrm{IP}}\right) \\
& \mathrm{SII}=\left[\left(\mathrm{A}_{\mathrm{IP}}-\mathrm{A}_{\mathrm{OP}}\right) / \mathrm{A}_{\mathrm{IP}}\right] \times 100
\end{aligned}
$$

$\mathrm{ASR}<0.71$ 또는 $\mathrm{SII}>16.5 \%$ 이면 부신선종으로 진단할 수 있다 $\left(\mathrm{A}_{\mathrm{IP}}\right.$, 동위상 시 부신 종괴의 신 호강도; $\mathrm{Aop}$, 탈위상 시 부신 종괴의 신호강도; $\mathrm{SIP}$, 동위상 시 비장의 신호강도; $\mathrm{Sop}$, 탈위상 시 비장 의 신호강도)

지방부족 부신선종(lipid-poor adrenal adenoma)의 경우, 조영증강 전 CT의 감쇠계수가 높을 수록 신호강도가 적게 감소한다. 특히, 조영증강 전 CT에서 $30 \mathrm{HU}$ 이상을 보이는 부신선종의 경 우 화학변위 MR 영상의 민감도는 $13 \%$ 정도로 보고되어 대부분 진단이 불가능하다(20, 21). 따라 서 조영증강 전 CT 상 $20 \mathrm{HU}$ 이상의 감쇠계수를 보이는 부신우연종을 지방부족 부신선종으로 진 단하기 위해서는 다음에 기술할 조영증강 CT가 필요하며, 화학변위 MR 영상은 다음과 같은 경우 에 제한적인 추가 검사로 이용함이 적절하다고 생각된다.

- 임신부, 소아, 기타 방사선 노출을 최소화하여야 하는 경우 
• CT에 사용되는 요오드화 조영제에 과민반응이 있는 경우

- 신기능이 저하되어 있는 경우

\section{부신 CT (Adrenal Protocol CT)}

부신 CT의 구성 프로토콜은 대개 조영증강 전 영상, 조영제 주입 후 1 분 및 15 분(또는 10 분) 지 연영상으로 이루어진다. 부신선종은 내부에 미세한 혈관망(fine microvascular network)을 가지 고 있어, CT 상 빠른 조영증강 및 씻김 현상(rapid enhancement and washout)을 보인다. 다른 부신우연종들, 특히 과혈관성 종양들 역시 조영증강 및 씻김을 보이지만, 부신선종이 더 빠른 조 영증강과 씻김을 보여, 15 분 지연영상을 촬영 시 부신선종을 다른 부신우연종들과 감별이 가능하 다(22). 부신 CT에서 부신선종을 진단할 수 있는 정량적 지표는 다음과 같으며, 셋 중 하나라도 만 족 시 부신선종을 진단할 수 있다. 특히 조영증강 후 얻을 수 있는 지표들은 지방부족 부신선종을 진단하는 데 큰 도움이 된다(Fig. 3).

•조영증강 전 CT감쇠계수: $10 \mathrm{HU}$ 이하

- 절대적 세척 값(absolute percentage washout value; 이하 APW): $60 \%$ 이상(15분 지연영상 사용 시) 또는 $50 \%$ 이상(10분 지연영상 사용 시)

• 상대적 세척 값(relative percentage washout value; 이하 RPW): 40\% 이상 $\mathrm{APW}$ 및 $\mathrm{RPW}$ 의 계산 공식은 다음과 같다.

$$
\begin{aligned}
& \mathrm{APW}=\left[\mathrm{HU}_{1 \min }-\mathrm{HU}_{15 \min }\right] /\left[\mathrm{HU}_{1 \min }-\mathrm{HU}_{\text {unenhanced }}\right] \times 100(\%) \\
& \mathrm{RPW}=\left[\mathrm{HU}_{1 \text { min }}-\mathrm{HU}_{15 \min }\right] /\left[\mathrm{HU}_{1 \min }\right] \times 100(\%)
\end{aligned}
$$

$\mathrm{HU}_{1 \mathrm{~min},}, 1$ 분 조영증강영상에서 병변의 감쇠계수; $\mathrm{HU}_{15 \mathrm{~min}}, 15$ 분 지연영상에서 병변의 감쇠계수

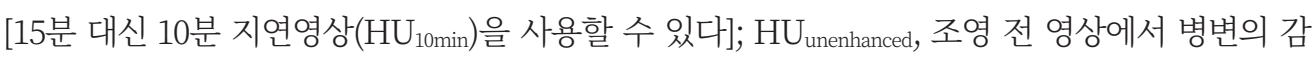
쇠계수

부신선종과 선종이 아닌 다른 종양의 감별에 있어 부신 CT의 진단적 민감도와 특이도는 각각 86 100\%, 92 100\%로 보고되어 있으며, 정확도는 98\%에 이른다(23). 10분 지연영상보다는 15분 지연영상을 사용하였을 때 진단의 민감도가 올라가는 것으로 알려져 있다. 부신 CT는 삼중시기 영상(three phase CT)이며 요오드화 조영제를 사용하는 영상이므로, 신기능저하 환자에서 급성 신손상(acute kidney injury)의 잠재적 위험성 및 방사선 조사량 증가 등의 단점이 있다. 그러므 로 부신 CT를 시행할 때, 먼저 조영증강 전 CT를 얻고 부신우연종의 감쇠계수를 측정하여 지방풍 부 부신선종을 감별한 후, $10 \mathrm{HU}$ 를 초과할 때만 조영증강 영상을 얻는 것이 상기 단점을 최소화 하기 위해서 바람직하나, 현실적으로는 의료인력 부족 및 환자의 CT실 체류시간 증가 등의 어려 움이 있다.

복부의 CT는 평가하고자 하는 장기나 질환에 따라 각각 다른 프로토콜의 다중시기 영상(multiphasic CT)을 얻는 경우가 많으며, 이때 발견되는 부신우연종에서 추가적 부신 CT 촬영 없이 해 당 프로토콜을 사용하여 부신선종을 감별할 수 있다면 환자의 방사선 조사량 증가와 반복된 조영 
Fig. 3. Calculation of the APW and RPW using adrenal CT of a 29-year-old woman with Cushing's syndrome. A-C. A 2.2-cm well-defined ovoid mass is seen in the left adrenal gland, which was pathologically confirmed as adrenal adenoma. The attenuation values are 15.3, 128.5, and 46.1 in the unenhanced (A), 1-min delayed (B), and 10-min delayed (C) phases, respectively. APW and RPW, which are $72.8 \%$ and $64.1 \%$, respectively, are with the reference values (50\% and 40\%, respectively) for diagnosing adrenal adenoma. $\mathrm{APW}=$ absolute percentage washout, RPW = relative percentage washout
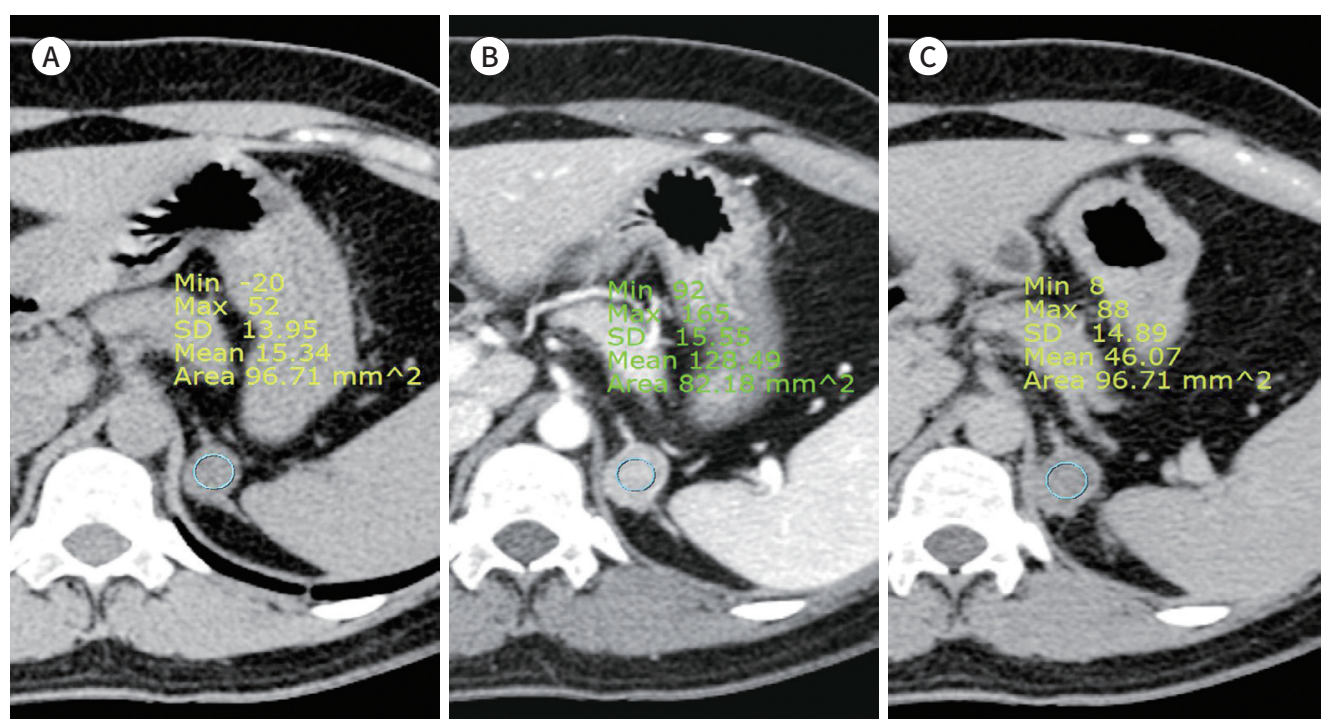

제 사용으로 인한 신손상 위험을 피할 수 있다. Park 등(24)의 연구에서, 보통의 부신 CT의 1 분 및 15 분 지연영상 대신 간 CT의 문맥기 및 180 초 지연기 영상을 사용하였을 때의 RPW가 $20 \%$ 를 초 과하면 부신선종의 진단 정확도가 $88 \%$ 에 이른다고 보고되었다. Liu 등(25) 역시 문맥기 및 200초 지연기 영상을 사용하여 구한 RPW의 부신선종의 진단능을 평가하였으며, RPW가 $30 \%$ 이상일 때 86\%의 진단 정확도를 보임을 보고하였다. 또한 동맥기 및 정맥기 영상으로 구성된 역동적 조 영증강 복부 CT 영상에서 부신우연종이 비균질한 조영증강을 보이고 동맥기에서 매우 강한 조영 증강(110 HU 이상)을 보이면, 부신선종보다는 크롬친화세포종(pheochromocytoma)을 시사한 다는 연구 결과도 있다(26). 이상의 결과에서 보듯이 간 CT 등의 다른 다중시기 영상 복부 CT 역시 부신선종과 선종이 아닌 다른 종양의 감별에 도움을 줄 수 있다. 그러나 이전 또는 현재의 암 병력 이 있는 경우, 부신우연종이 비균질한 감쇠(heterogeneous attenuation), 내부 괴사(internal necrosis), 불규칙한 경계(irregular margin) 등의 악성을 시사하는 소견을 가지는 경우에는 부신 전 이암을 감별하기 위해 높은 진단능이 요구되므로, 필요할 경우 부신 CT를 촬영하여야 한다.

\section{부신선종과 부신 전이암의 감별}

이전 암 병력 여부와 관계없이 부신우연종 중 가장 많은 비율을 차지하는 것은 부신선종이다. 그러나 부신의 전이암 역시 부신우연종 중 약 $2 \%$ 를 차지하고 있으며, 특히 다른 장기에 원발암을 가지고 있는 환자에서 발견되는 부신우연종의 경우 전이암의 빈도가 $73 \%$ 까지 증가함이 알려져 있다(27). 따라서 부신선종과 부신 전이암의 감별은 환자의 치료 방침 결정과 예후 예측에 매우 중 요하다. 특히, 세포질 내부에 부신선종과 마찬가지로 지방성분을 많이 포함하고 있으며 과혈관성 
종양인 간세포암(hepatocellular carcinoma)이나 투명세포아형 신장세포암(clear cell type renal cell carcinoma)의 경우, 부신선종과 비슷한 영상 소견을 화학변위 MR 영상과 부신 CT 상에 서 보일 수 있어, 감별이 어려운 경우가 많다(28). 따라서 추적관찰 CT를 시행하여 병변의 크기 및 모양의 변화 여부와 양상을 평가하는 것이 전이암 감별에 중요하다(9). Fluorodeoxyglucose PET/ $\mathrm{CT}$ 를 추가적으로 검사하면 부신 CT 단독으로 평가할 때보다 부신 전이암의 진단 정확도를 높일 수 있으며, 이 경우 간의 정상 핵종 섭취와 비교하여 병변의 섭취가 더 높을 때를 기준으로 삼아야 한다고 보고되어 있다(29). CT, MR, PET-CT를 포함한 영상검사로 잘 감별되지 않는 경우 영상유 도 하에서 경피적 조직검사를 고려해 볼 수 있다.

\section{부신우연종의 영상의학적 접근}

부신우연종을 접하였을 때 다음과 같이 3단계로 감별진단에 접근할 수 있다.

\section{1단계: 양성임을 진단할 수 있는 영상 소견}

흉복부 영상에서 우연히 부신 종괴를 접하게 되면 이를 감별진단하기 위해 생화학적 검사 결과 를 참조해야 하거나, 추가적인 영상검사를 시행해야 하는 경우가 많다, 그러나, 영상검사에서 보 이는 소견만으로 특정한 감별진단에 이르거나, 또는 양성 및 악성을 감별할 수 있는 경우가 있다. 따라서, 부신우연종의 영상의학적 접근의 첫 단계는 '그 자체로 양성임을 진단할 수 있는 영상 소 견'을 찾아보는 것이다. ACR 권고안에서 언급하는 '양성임을 진단할 수 있는 영상 소견'은 다음과 같다(8).

- 육안적으로 확인 가능한 지방(macroscopic fat) (예: 골수지방종)

• $10 \mathrm{HU}$ 이하의 낮은 CT 감쇠계수(예: 지방풍부 부신선종)

•MR 탈위상에서 동위상에 비해 신호 감소(signal drop) (예: 지방풍부 부신선종)

·출혈을 시사하는 조영증강되지 않는 높은 CT 감쇠계수(예: 부신 혈종)

이에 속하는 병변으로는 골수지방종(myelolipoma), 낭종(cyst) 및 가성 낭종(pseudocyst), 부 신 혈종(hematoma), 지방풍부 부신선종 등이 있다(13, 30, 31). 충분한 범위를 포함하여 측정한 종괴의 CT 감쇠계수가 $10 \mathrm{HU}$ 이하일 경우 높은 민감도 및 특이도로 부신선종을 진단할 수 있으므 로, 이 역시 ‘그 자체로 양성임을 진단할 수 있는 영상 소견’에 포함될 수 있다.

양성임을 진단할 수 있는 영상 소견(diagnostic benign imaging feature)을 가지는 부신 종괴 들은 다음과 같다.

\section{골수지방종(Adrenal Myelolipoma)}

골수지방종은 골수와 비슷한 성숙 지방세포(mature adipocytes)와 조혈세포(hematopoietic cells)로 이루어진 부신의 양성 종양이다(32). Song 등(33)의 연구에서 골수지방종은 부신우연종 의 $6 \%$ 정도를 차지하는 것으로 보고되었다. 대개는 임상 증상을 일으키지 않으며, 우연히 다른 목 적으로 촬영한 CT에서 발견되는 경우가 많다. 그러나 크기가 큰 경우, 후복막강 출혈과 통증 등의 
증상을 일으키기도 한다(34)

CT에서 주변 후복막강의 지방과 비슷한 육안적 지방감쇠가 종괴에서 보이면 쉽게 진단이 가능 하며, 비조영증강 CT에서 피하지방과 비슷한 저음영 종괴로 -30 HU 이하의 감쇠계수를 보이면 진단이 가능하다는 연구가 있다(35). 그러나 다른 종괴들 역시 육안적 지방감쇠를 보일 수 있으므 로, 육안적 지방 자체는 골수지방종의 진단 기준이 될 수 없으며, 이 점이 신장의 혈관근지방종(renal angiomyolipoma)과의 차이점이라 할 수 있다(36). Zhang 등(37)의 연구에서 부신피질암의 $10 \%$ 정도는 육안적 지방을 종괴 안에 보일 수 있음이 알려져 있다. 골수지방종은 $80 \%$ 에서 종괴 의 반 이상이 지방감쇠를 보이고, $32 \%$ 에서는 종괴의 $90 \%$ 이상이 지방감쇠를 보인다(38). 종괴의 $50 \%$ 이상이 육안적 지방으로 이루어져 있으면 골수지방종으로 진단할 수 있다는 연구도 있다 (Fig. 4) (39).

\section{부신 낭종 및 가성 낭종(Adrenal Cyst and Pseudocyst)}

부신의 낭성 병변은 낭종과 가성 낭종으로 분류할 수 있고, 낭종은 다시 상피 낭종(epithelial

Fig. 4. Adrenal myelolipoma in the left adrenal gland of a 39-year-old man.

Unenhanced CT shows a 7.5-cm well-demarcated round mass, mainly composed of macroscopic fat in the left adrenal gland. The mass had a high-attenuation focus in the anterior portion (41 HU, arrow), suggestive of hemorrhage. The left adrenalectomy specimen revealed that the mass was filled with fat and some portion of hemorrhagic necrosis, consistent with myelolipoma.

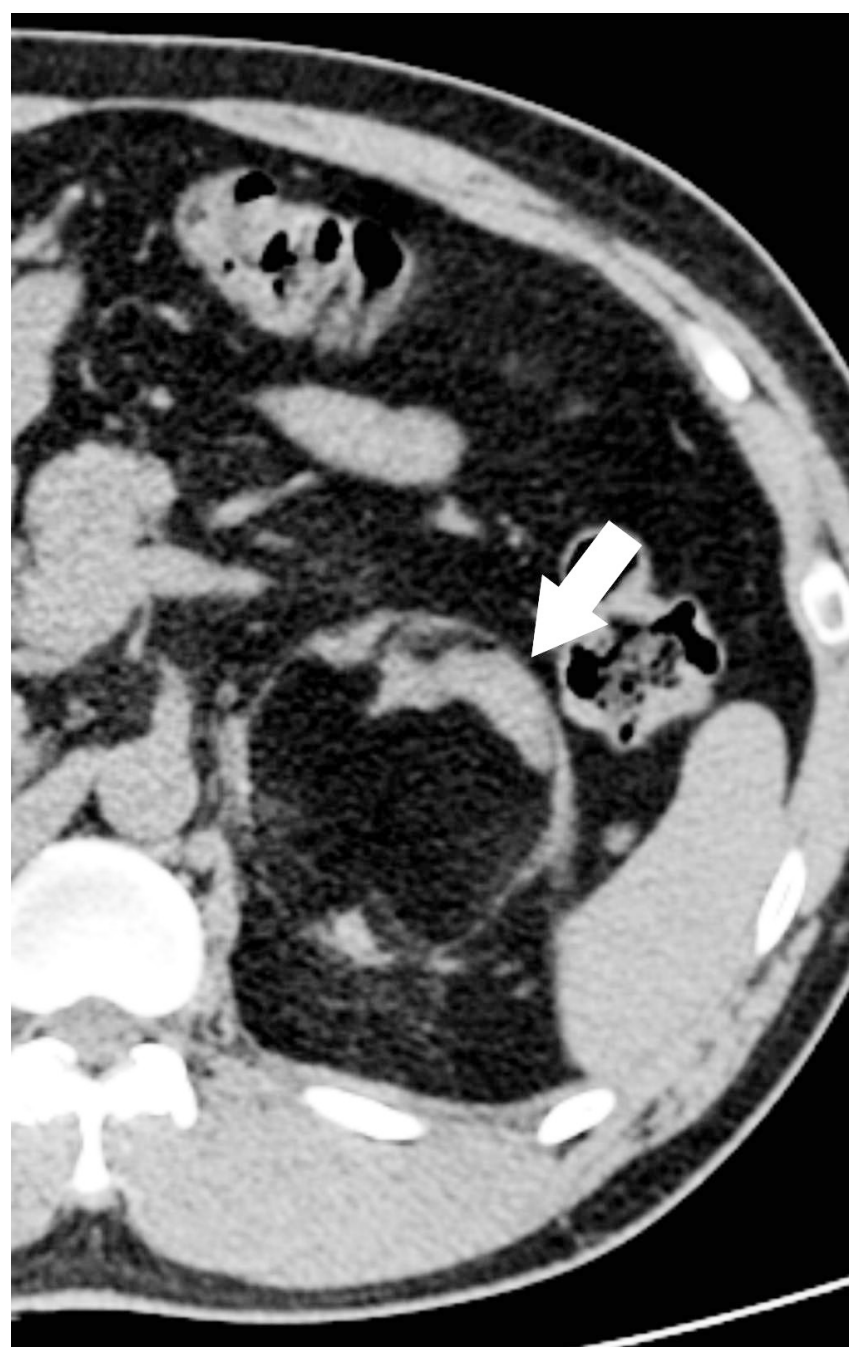


Fig. 5. Adrenal cyst in the left adrenal gland of a 40-year-old man.

A, B. On MRI, the masses (arrows) show high signal intensity on the T2-weighted image (A) and low signal intensity on the T1-weighted image (B) without internal soft tissue components or internal enhancement. The presumptive diagnosis was adrenal cyst.
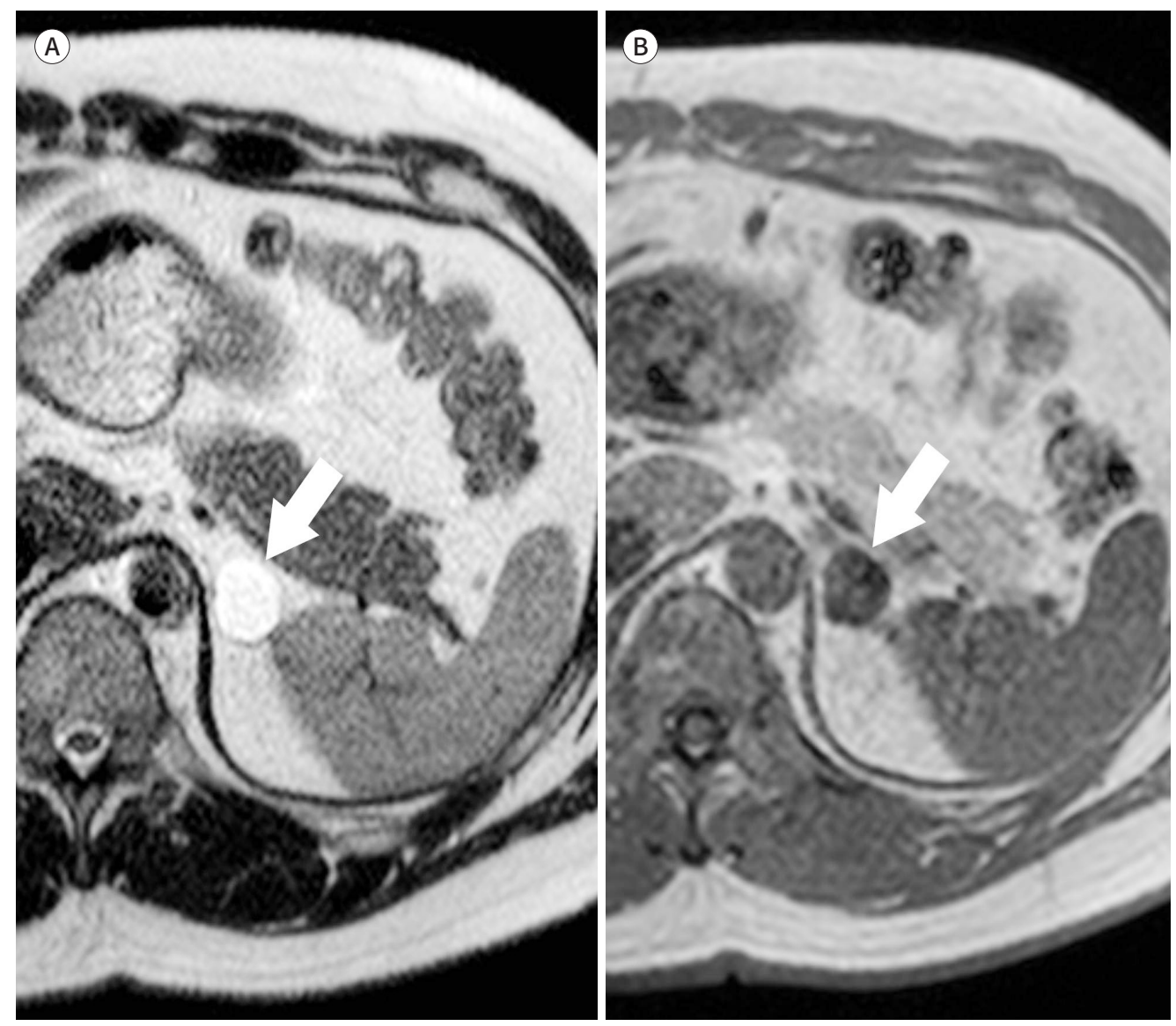

cyst), 내피 낭종(endothelial cyst), 기생충성 낭종(parasitic cyst)으로 구분된다. CT 및 MR 상에 서 전형적인 얇은 벽 내부에 $20 \mathrm{HU}$ 이하의 물 성분이 채워진 영상 소견을 보이며, 조영증강은 없 다(Fig. 5) (36). 낭종의 벽에는 석회화가 보일 수 있으며, Rozenblit 등(40)의 연구에서는 약 51\% 의 낭성 병변에서 벽 석회화가 있다고 보고되었다(40). 단순 낭종(simple cyst)으로도 알려진 내피 낭종은 전체의 $45 \%$ 를 차지하며, 가성 낭종(39\%) 및 기생충성 낭종(9\%) 순으로 분포한다. 가성 낭 종은 내피 낭종에 비해 더 두꺼운 벽과 낭종 내부의 격벽을 가질 수 있으며, 이전 부신의 출혈이나 허혈의 과거력과 관련이 있다(41). 기생충성 낭종은 이전 포충 감염(echinococcus infection)이 원인이 되어 생기며, 다낭성의 종괴로 보여 내피 낭종 및 가성 낭종과 구분된다(36).

\section{부신 혈종(Hematoma)}

부신 혈종의 원인은 외상성과 비외상성으로 나눌 수 있으며, 비외상성 원인으로는 응고장애(coagulopathy), 출혈성 경향(bleeding diathesis), 패혈증이나 임신, 수술 등의 스트레스성 상황, 그 리고 출혈을 동반하는 종괴 등이 있다(36). CT에서 조영증강 전 50 90 HU 의 감쇠계수를 보이는 원형 또는 타원형의 종괴로 보이며, 수 일 또는 수 주에 걸쳐 크기와 음영이 감소한다(42). 위험 요 
Fig. 6. Adrenal hematoma in the right adrenal gland of a 42-year-old man after a traffic accident. A, B. Unenhanced CT (A) shows a 2.5-cm ovoid mass in the right adrenal gland (arrows). On the post-contrast scan (B), the mass shows high attenuation ( $58 \mathrm{HU})$ and no enhancement. The final diagnosis was adrenal hemorrhage, considering the history of trauma.
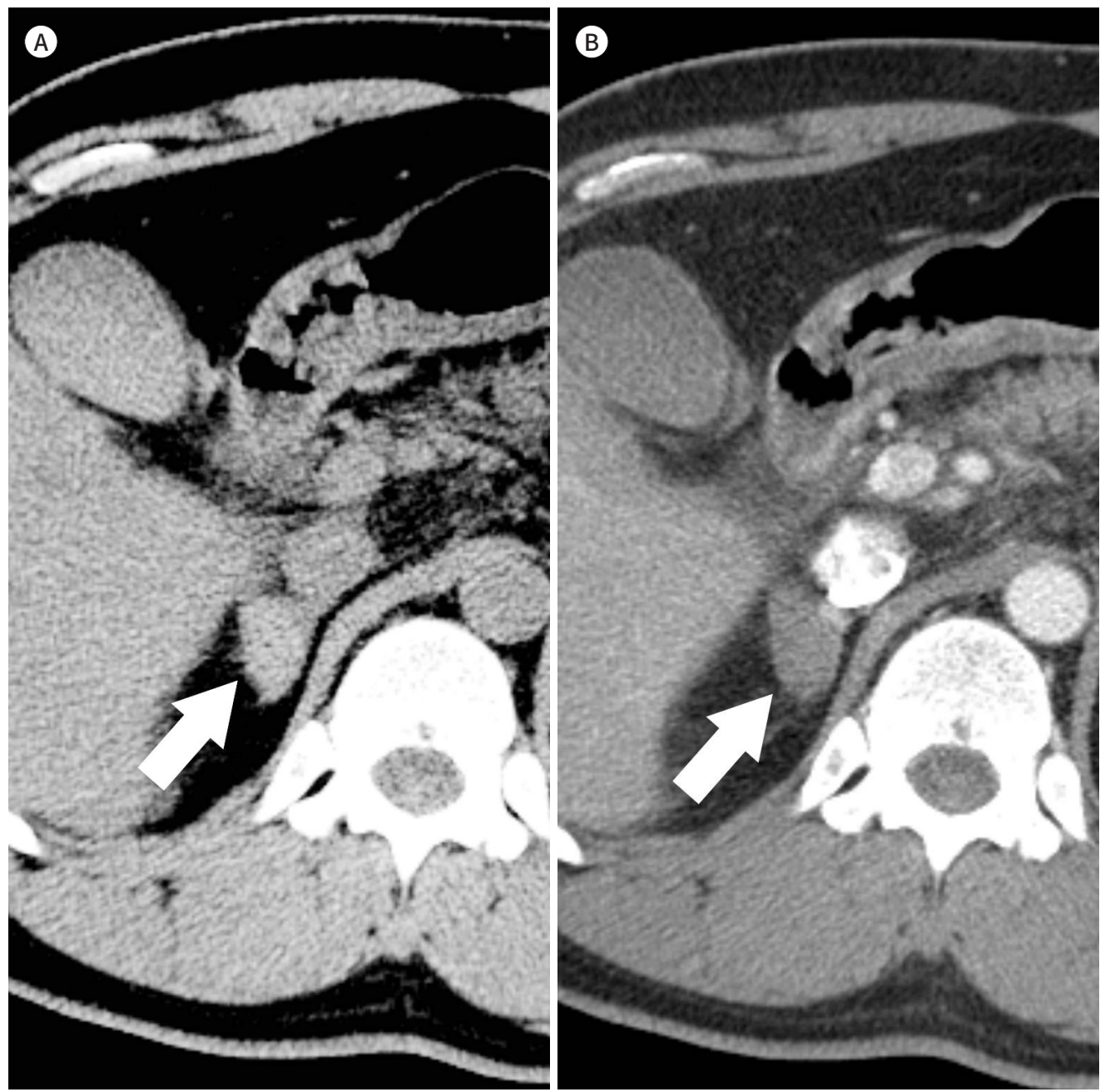

인이 없는 성인에서 갑자기 발생한 부신 혈종의 경우 기저질환으로 부신의 출혈성 종양(hemorrhagic neoplasm)이 있을 수 있으며, 골수지방종, 크롬친화세포종, 그리고 부신피질암 등을 감별 하여야 한다. 상기 종양들의 조영증강되는 고형 성분을 확인하는 것이 기저 종양의 유무를 감별하 는 데 도움이 된다(Fig. 6) (36).

\section{부신 혈관종(Adrenal Hemangioma)}

혈관종은 드문 부신종양이며 영상 소견은 간의 혈관종과 유사하다. 역동적 조영증강 CT에서 동 맥기에 종괴의 주변으로 분포하는 결절성 조영증강(peripheral nodular enhancement)이 특징 이며, 지연기 CT에서는 종괴 중심까지 조영증강이 파급되는 모습(contrast fill-in)을 관찰할 수 있 다(Fig. 7) (13, 36, 39). 내부에 정맥결석으로 인한 석회화가 보일 수 있다(43). 
Fig. 7. Adrenal hemangioma in the left adrenal gland of a 69-year-old woman.

A-C. Unenhanced CT (A) shows a 5.7-cm homogeneous low-attenuation mass in the left adrenal gland. Curvilinear calcification is noted in the mass (arrow). The mass shows peripheral nodular enhancement pattern in the 1-min delayed phase (B) and delayed centripetal enhancement in the 10-min delayed phase (C). The left adrenalectomy specimen revealed that the mass had dilatated vascular networks and dystrophic calcifications, suggestive of hemangioma.
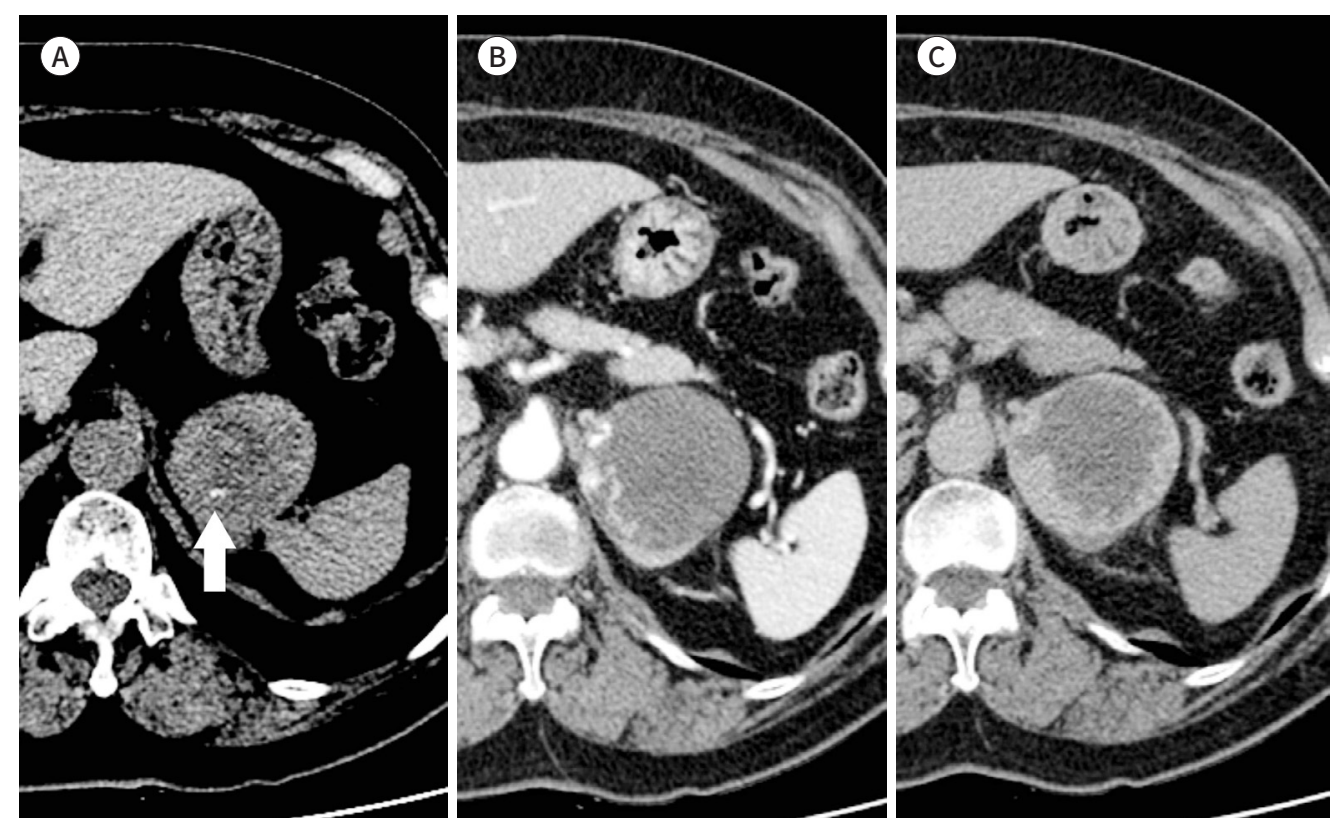

Table 1. Diagnostic Features of Adrenal Adenoma on Various Imaging Modalities

\begin{tabular}{ll}
\hline \multicolumn{1}{c}{ Imaging Modality } & \multicolumn{1}{c}{ Diagnostic Features of Adrenal Adenoma } \\
\hline Unenhanced CT & Hypodense mass \\
& $\leq 10 \mathrm{HU}$ \\
Chemical shift MR & Signal drop at opposed phase compared to in-phase \\
& ASR $<0.71$ \\
& SII $>16.5 \%$ \\
Adrenal CT with 10 or 15 min delayed scan & Early wash-in and washout \\
& APW $\geq 50 \%$ (when using 10 min delayed scan) \\
& APW $\geq 60 \%$ (when using 15 min delayed scan) \\
& RPW $\geq 40 \%$ (regardless of delay time) \\
Multiphase CT other than adrenal CT & Early wash-in and washout \\
& RPW $\geq 40 \%$ \\
\hline
\end{tabular}

$\mathrm{APW}=$ absolute percentage washout, $\mathrm{ASR}=$ adrenal-to-spleen ratio, $\mathrm{HU}=$ Hounsfield unit, $\mathrm{RPW}=$ relative percentage washout, $\mathrm{SII}=$ signal intensity index

\section{부신선종(Adrenal Adenoma)}

부신선종의 대부분은(60 90\%) 지방풍부 부신선종이고, 조영증강 전 CT에서 $10 \mathrm{HU}$ 이하의 감 쇠계수를 보이는 것으로 진단이 가능하며 이의 민감도 및 특이도는 각각 $71 \%$ 와 $98 \%$ 에 이른다 $(9$, $12,13)$. 조영증강 전 CT에서 $10 \mathrm{HU}$ 보다 큰 감쇠계수를 보이는 지방부족 부신선종(lipid poor adrenal adenoma)의 경우 화학변위 $\mathrm{MR}$ 영상 및 부신 $\mathrm{CT}$ 를 촬영하여 높은 정확도로 진단이 가능하 다(Table 1). 
2단계: 종괴의 크기가 $4 \mathrm{~cm}$ 이상인가?

부신우연종에 그 자체로 양성임을 진단할 수 있는 영상 소견이 없는 경우, ACR 권고안에서는 그다음 단계로 크기에 따라 평가를 달리할 것을 권고하고 있으며, 특히 $4 \mathrm{~cm}$ 이상의 병변의 경우 다른 암의 과거력이 없거나 그 자체로 양성임을 진단할 수 있는 소견이 없다면 원발성 부신 피질 암을 감별하기 위해 조직검사 없이 바로 수술을 권고하고 있다(8). 대한내분비학회의 부신우연종 진료지침에서도 $4 \mathrm{~cm}$ 이상의 부신우연종은 악성 가능성이 있으므로 호르몬 과다 분비와 무관하 게 수술을 고려한다고 기술하고 있다(44). $4 \mathrm{~cm}$ 이상의 큰 크기 외에도, 종괴 내부가 균질하지 않 거나, 불규칙한 경계나 비균질성 조영증강 또는 주변조직 침범이나 전이를 보이는 경우에 악성 부 신 종괴를 시사한다(45).

다른 암의 과거력이 있는 경우 부신 전이암을 고려하여야 한다. 부신 전이는 대부분의 암에서 원격전이로 간주되므로 수술의 적응증이 되지 않는 경우가 많다. 이런 경우 확진 및 항암화학요법 을 위해 경피적 생검(percutaneous biopsy)이 필요하게 되며, 초음파 또는 CT 유도하에 시행할 수 있다. 부신종양의 조직검사 시 원발성 부신 피질암의 경우 생검 경로를 통한 암의 파종이 일어 날 수 있어 생검보다는 수술을 통한 일괄절제를 고려해야 하며(31), 크롬친화세포종의 경우 부신 위기(adrenal crisis)를 초래할 수 있어 생검 전 반드시 감별진단하여야 한다(46).

\section{3단계: $1 \sim 4 \mathrm{~cm}$ 사이의 부신우연종-부신선종인가 아닌가?}

상기 모두에 해당하지 않는, 크기 1 4 cm 사이의 양성을 시사하는 영상 소견이 없는 부신우연 종의 경우, 부신선종과 기타 다른 부신종양과의 감별진단이 중요한데, 그 이유는 대부분의 부신우 연종은 양성 종양인 비기능성 부신선종이므로 부신선종을 진단하는 것이 부신우연종의 양성 및 악성을 감별하는 데 큰 비중을 차지하기 때문이다. 또한 이전 영상이 있을 경우 크기 변화를 평가 하는 것이 양성 및 악성을 감별하는 데 중요한 역할을 한다. 따라서 2017년 ACR 권고안에서는, 먼 저 이전 영상이 있을 경우 1 년 이상 크기 변화가 없다면 양성으로 간주하고 더 이상의 추적관찰은 필요하지 않다고 권고한다(8). 만약 새로이 나타난 병변이거나 크기 변화가 있다면, 이전 암 병력 유무에 따라 추가 검사를 권고하는데, 암 병력이 있는 경우 조직검사나 PET-CT를, 암 병력이 없는 경우는 부신선종의 감별을 위해 부신 CT 또는 종양 절제술을 권고하고 있다.

이전 영상이 없는 경우, $1 \sim 2 \mathrm{~cm}$ 사이의 부신우연종은 양성의 가능성이 높으므로, 1 년 후 부신 CT로 추적관찰 할 것을 권고하고 있다(8). 그러나, 현실적으로 정확한 감별진단을 위해서 바로 부 신 CT나 MRI 등의 추가적 영상검사를 하는 경우가 많다. 부신우연종의 크기가 $2 \mathrm{~cm}$ 이상이거나, 암 병력이 있는 환자에서는, 부신 CT를 촬영하여 부신선종과 전이암 등의 다른 부신우연종을 감 별진단한다. 상기 기술한 내용을 모식도로 정리하였다(Fig. 8).

\section{기타 감별이 필요한 부신 종괴}

\section{림프종(Lymphoma)}

부신의 림프종은 주로 비호지킨성 림프종이며, 원발성보다는 동측의 신장이나 후복막강에 발 
Fig. 8. Flowchart for the evaluation of adrenal incidentaloma.

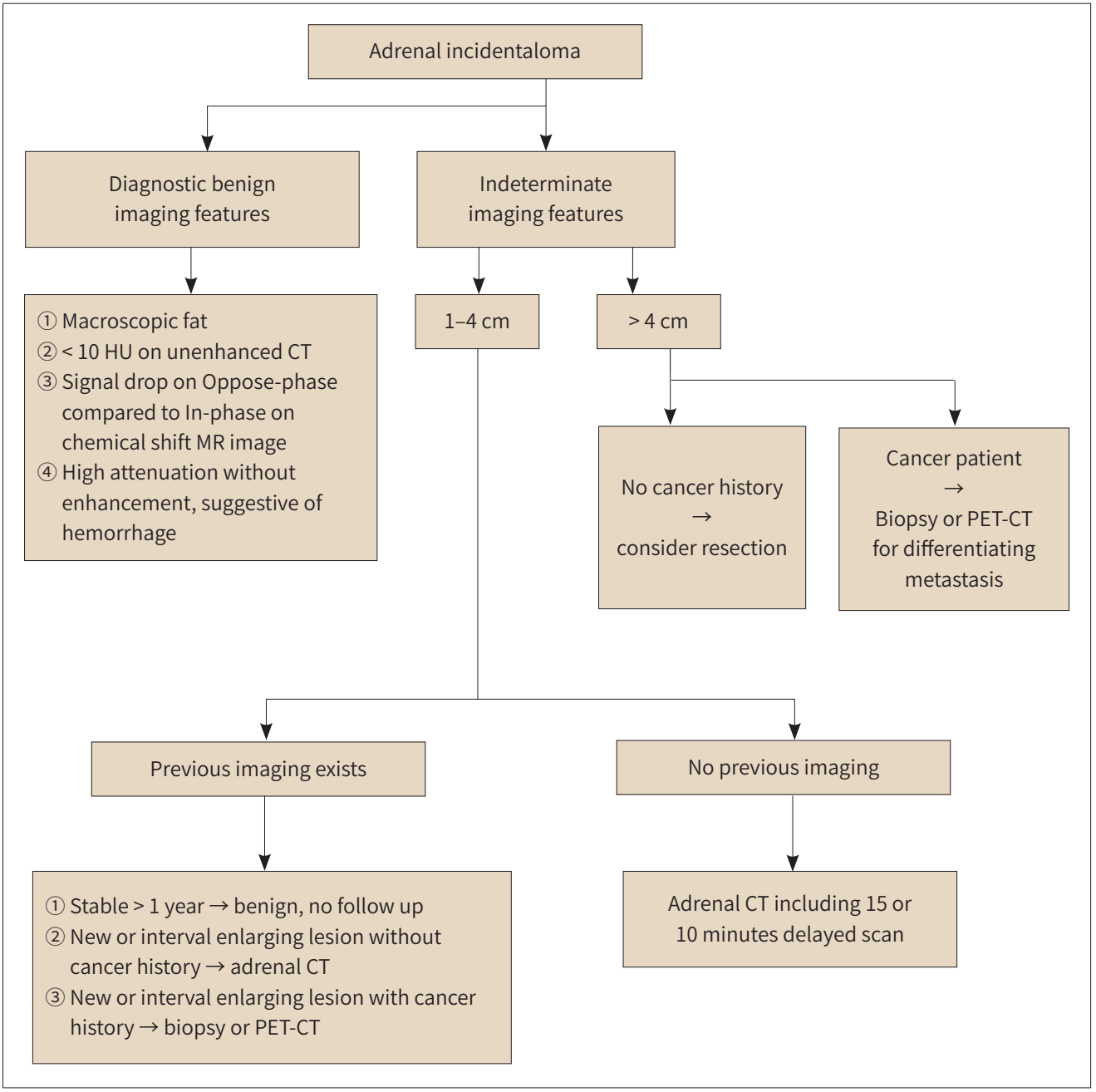

생한 림프종과 관련하여 이차성으로 나타나는 경우가 많다. 약 $50 \%$ 에서 양측 부신을 모두 침범한 다 $(47,48)$. CT에서 비교적 균질한 고형 종괴로 보이며, 조영증강 시 천천히 조영증강되나 비특이 적이다(Fig. 9) $(9,13)$. 영상검사만으로 림프종을 다른 부신 전이암과 구분하는 것은 불가능하며, 임상 상황을 고려하여 판단하여야 한다.

\section{신경절신경종(Ganglioneuroma)}

신경절신경종은 교감신경절에서 발생하는 양성 종양이며, 약 20 30\%는 부신의 수질(medulla) 에서 발생한다(13). 예후는 매우 좋아 절제술 후에는 거의 재발하지 않는다.

영상의학적으로 경계가 매우 좋은 타원형의 종괴로 보이며, 주변 혈관을 둘러쌀 수는 있으나 혈 관강 내부를 침범하지는 않는다. 내부에 점액질 성분(myxoid matrices)이 풍부하여, 점진적으로 천천히 조영증강되는 양상을 보인다. $\mathrm{MR}$ 에서는 $\mathrm{T} 1$ 강조영상에서 낮은 신호강도를 보이며, $\mathrm{T} 2$ 강 조영상에서는 내부 점액질 성분의 양에 따라 중간 또는 높은 신호강도를 보일 수 있다. T2 강조영 상에서 곡선형태의 저신호강도 줄무늬로 구성된 소용돌이 모양(whorled appearance)을 나타내 
Fig. 9. Diffuse large B cell lymphoma in the right adrenal gland of a 42-year-old man.

A-C. Unenhanced CT (A) shows an ovoid, homogeneous mass in the right adrenal gland (arrows). Arterial (B) and portal (C) phase scans shows poor homogeneous enhancement and a few cystic foci in the mass. The adrenalectomy specimen was pathologically confirmed as diffuse large B cell lymphoma.
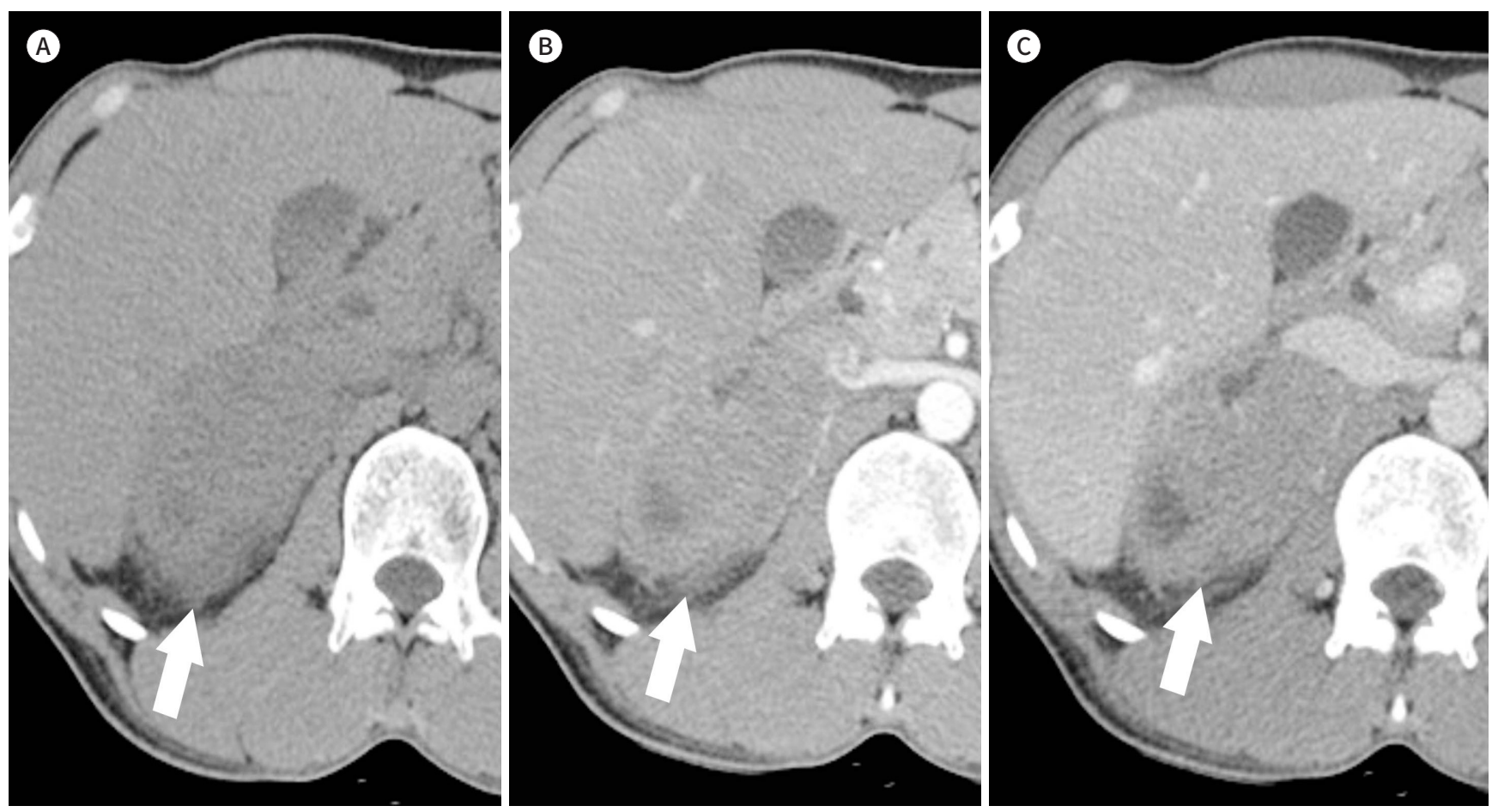

기도 한다(Fig. 10) (49).

\section{크롬친화세포종}

크롬친화세포종은 부신수질의 크롬친화세포(chromaffin cell)에서 발생하는 종양으로 고혈압, 심계항진, 발한 등의 임상 증상을 보인다. 진단은 생화학적 검사로 내려지며, 증상 유무와 상관없 이 모든 부신우연종 환자들에게서 크롬친화세포종을 배제하기 위해 혈장 유리 메타네프린(metanephrine) 혹은 24 시간 소변 분획구역(fractioned) 메타네프린을 포함한 대사 검사를 시행하여 야 한다(44). 대부분의 갈색세포종은 노르에피네프린, 에피네프린, 드물게는 도파민 등 여러 가지 카테콜아민(catecholamines)을 분비하며, 불규칙하게 분비되는 카테콜아민과 달리 그 대사물인 메타네프린은 지속적으로 방출되므로, 메타네프린을 측정하면 고혈압 등 증상이 동반되기 전에도 크롬친화세포종을 진단할 수 있다.

영상검사에서 크롬친화세포종은 주로 3 5 cm의, 부신선종보다는 크고 부신피질암보다는 작은 크기의 종양으로 보인다(50). CT에서 내부에 괴사, 낭성 및 점액성 변성, 출혈 등을 보일 수 있고, 조영제 주입 시 빠르고 강한 조영증강을 보이며 조영제 씻김의 정도는 경우에 따라 다양하다. 이 러한 비특이적인 영상 소견으로 인해 감별진단이 어려운 종양이며, 특히 크기가 작을 경우 균질한 종괴로 나타나고 내부의 변성으로 인해 조영증강 전 CT에서 낮은 감쇠계수, 그리고 강한 조영증 강과 씻김 현상으로 인해 부신선종과 감별이 어려운 경우가 많다 $(51,52)$. 이러한 크롬친화세포종 
Fig. 10. Ganglioneuroma in the right adrenal gland of a 28-year-old woman.

A, B. The well-defined ovoid mass in the right adrenal gland shows low signal intensity on the T1-weighted image (A) and heterogeneous high signal intensity on the T2-weighted image (B). Curvilinear low signal intensity foci (arrowheads) are seen in the mass on the T2-weighted image, with whorled appearance.

C. Dynamic contrast-enhanced T1-weighted images show slow gradual enhancement because of abundant internal myxoid matrices. Right adrenalectomy was performed, and the mass was pathologically confirmed as ganglioneuroma.
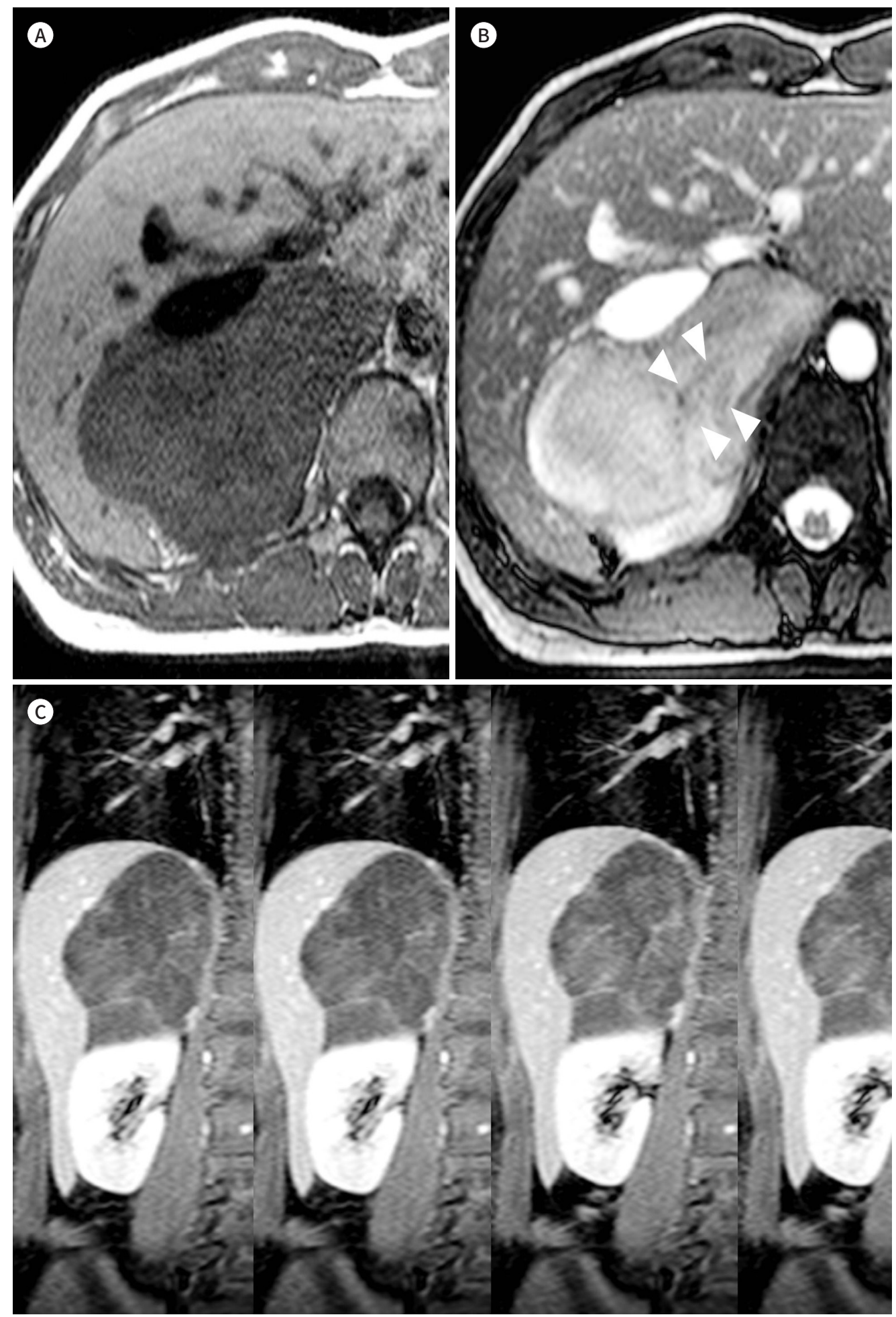
Fig. 11. Pheochromocytoma in the left adrenal gland of a 59-year-old man.

A-C. Adrenal CT (A, B) shows a well-circumscribed, markedly enhancing round mass (arrows) with areas of necrosis and cystic change in the left adrenal gland. In the MIBG scan (C), the left adrenal mass is very MIBG-avid. The adrenalectomy specimen was pathologically confirmed as pheochromocytoma.

MIBG = metaiodobenzylguanidine
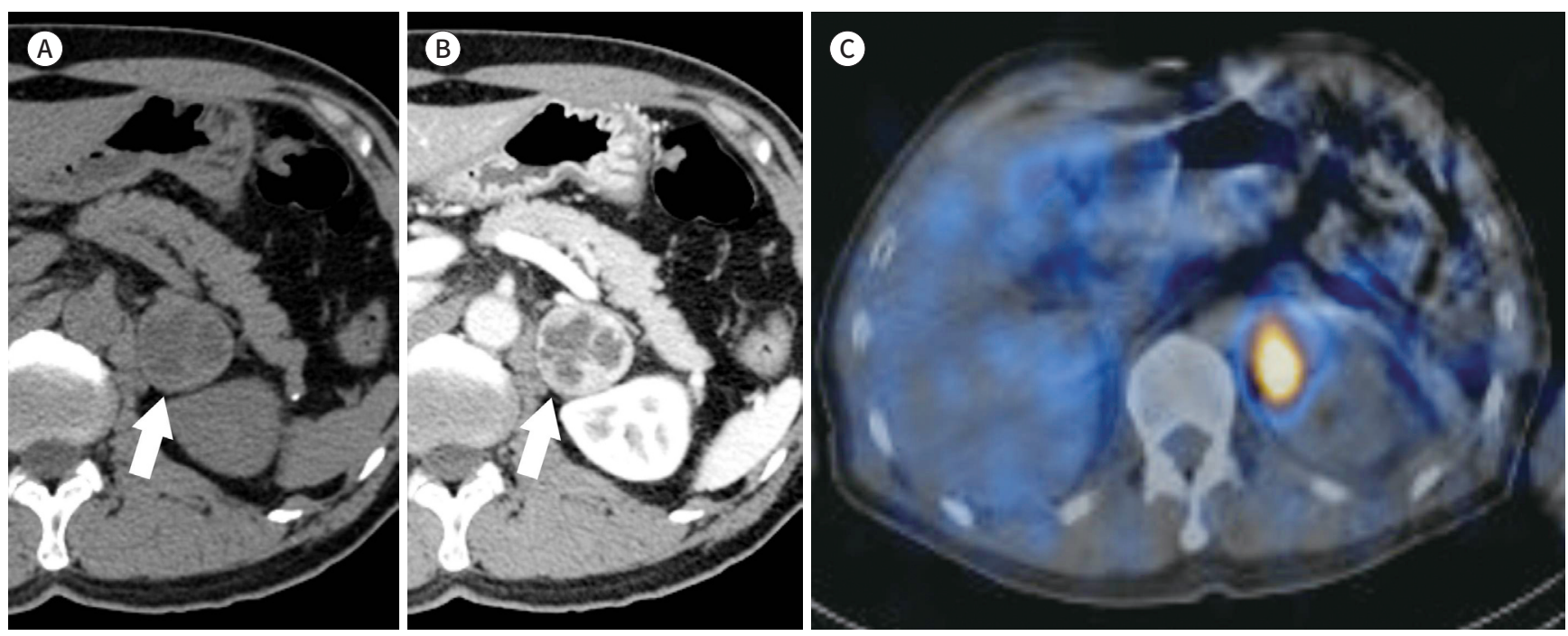

의 경우 $\mathrm{APW}$ 및 RPW 등의 정량적 지표도 부신선종의 기준을 만족시켜 부신선종으로 오진되 기도 하므로, 정량적 지표가 부신선종에 합당하더라도 매우 강한 조영증강을 보이는 경우에는 (> 120 150 HU) 크롬친화세포종의 가능성을 고려하여야 한다(53). ${ }^{123}$ I-metaiodobenzylguanidine (MIBG) scintigraphy는 95\%의 진단 정확도를 보여 크롬친화세포종의 감별 및 국소화(localization)에 사용된다(Fig. 11).

\section{부신피질암(Adrenocortical Carcinoma)}

100 만 명당 1 명 꼴로 발생하는 매우 드문 악성 종양이며, 예후는 좋지 않아 5년 생존율은 $37 \%$ 정도이다(36). 부신피질암의 60\%는 기능성 종괴이며, 쿠싱증후군(Cushing syndrome), 여성화 (feminization), 남성화(virilization), 또는 알도스테론 저하증(hyperaldosteronism) 등의 내분비 증상을 보인다 $(54,55)$. 비기능성 부신피질암의 경우 증상이 없기 때문에 더 늦게 발견되어, 발견 당시 $1 / 3$ 정도는 타 장기에 전이가 있다(56).

대부분 진단 당시 $6 \mathrm{~cm}$ 이상으로 측정되나 약 $15 \%$ 에서는 그 이하의 크기를 보이므로 부신선종 과 감별을 요한다. 영상검사상 조영증강 전 CT에서 $10 \mathrm{HU}$ 이상을 보이는 경우가 많으며, 조영증 강 시 중심부에 괴사를 동반하고 주변부는 불규칙적으로 조영증강된다. 내부에 석회화를 동반하 는 경우도 $30 \%$ 에서 보인다. $6 \mathrm{~cm}$ 이상의 큰 크기와 종괴 내부의 비균질성은 부신피질암의 진단에 가장 유용한 영상 소견이다(Fig. 12) (57). 부신피질암은 매우 침습적인 악성 종괴로 영상검사에서 주변 혈관이나 장기의 직접 침범 여부를 확인할 수 있다( 13,36$)$. 
Fig. 12. Adrenal cortical carcinoma in the right adrenal gland of a 61-year-old man.

A, B. A large $(9.2 \mathrm{~cm})$ mass is seen in the right adrenal gland. The mass shows high attenuation on the unenhanced image (A) and heterogeneous enhancement after the contrast media injection (B). There are ill-defined central low-attenuation areas, (arrowheads) suggestive of necrosis, and direct invasion with tumor thrombus formation to the adjacent inferior vena cava (arrow).
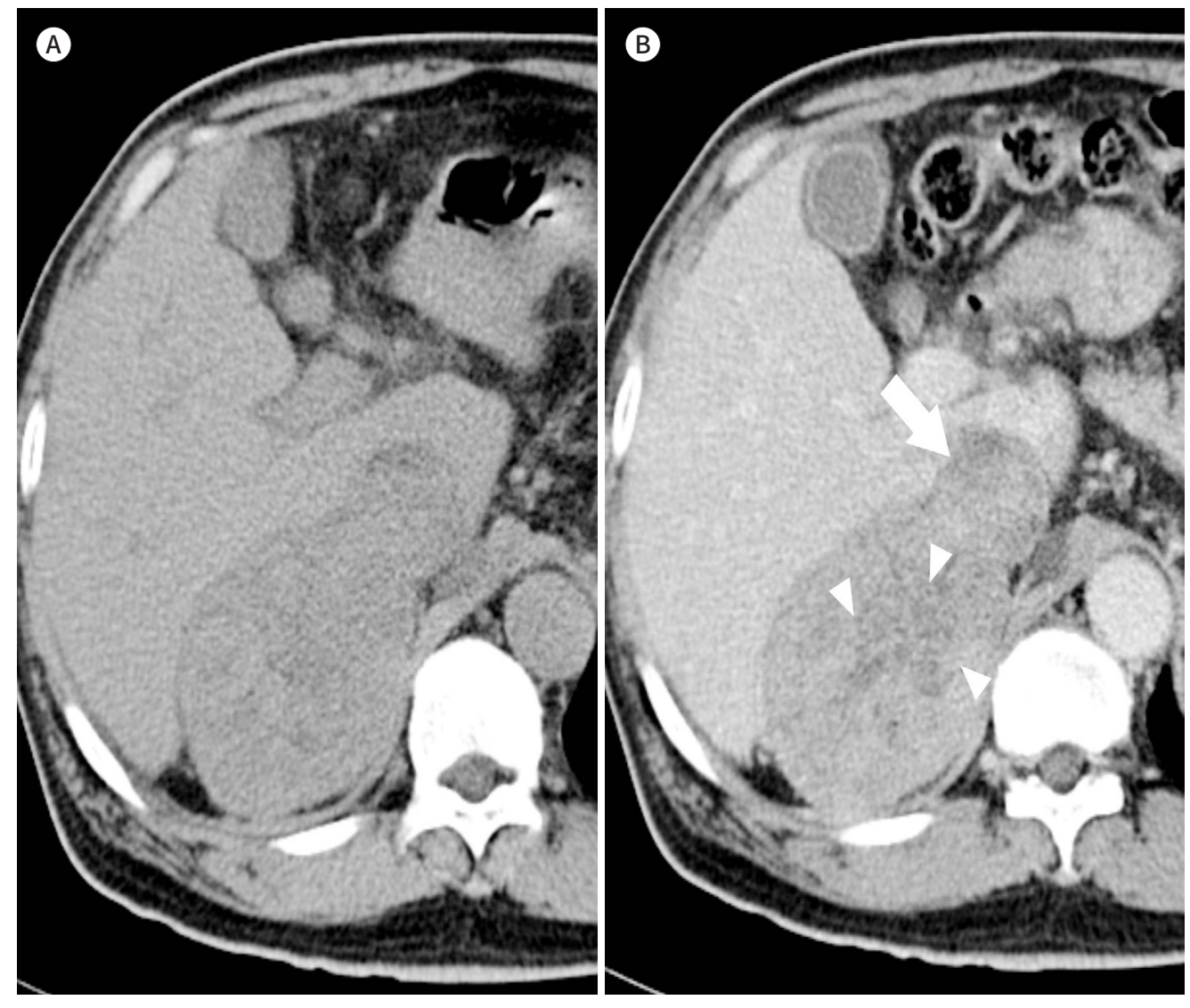

결론

부신우연종의 대부분은 비기능성 부신선종이며, 많은 경우 부신선종과 부신선종 외의 다른 부 신종양을 감별하는 것이 중요한 경우가 많다. 특히, 이전 암의 병력이 있거나 현재 타 장기에 원발 암을 가진 환자에서 발견된 부신우연종이 전이암인지를 감별하는 것은 환자의 치료와 예후 예측 에 매우 중요하다. 부신우연종의 감별진단에서 첫 번째 단계는 양성임을 진단할 수 있는 영상 소 견이 있는가를 판단하는 것이며, 영상 소견만으로 양성을 배제할 수 없다면 환자의 병력과 부신우 연종의 크기를 고려하여 적절한 추가 영상검사를 추천하고 시행하여야 한다. 간세포암이나 투명 세포아형 신장세포암 등의 부신 전이나 크기가 작은 크롬친화세포종 등은 부신선종과 비슷한 정 성적, 정량적 영상 소견을 보일 수 있어 감별에 특히 주의를 요한다.

\section{Author Contributions}

Conceptualization, all authors; data curation, L.M.S.; formal analysis, L.M.S.; investigation, L.M.S.; methodology, L.M.S.; project administration, all authors; resources, all authors; software, all authors; supervision, M.M.H., S.C.K.; validation, M.M.H., S.C.K.; visualization, L.M.S.; writing-original draft, L.M.S.; and writing-review \& editing, all authors. 


\section{Conflicts of Interest}

The authors have no potential conflicts of interest to disclose.

\section{REFERENCES}

1. Young WF Jr. Clinical practice. The incidentally discovered adrenal mass. N Engl J Med 2007;356:601-610

2. Blake MA, Cronin CG, Boland GW. Adrenal imaging. AJRAm J Roentgenol 2010;194:1450-1460

3. Willatt JM, Francis IR. Radiologic evaluation of incidentally discovered adrenal masses. Am Fam Physician 2010;81:1361-1366

4. Mansmann G, Lau J, Balk E, Rothberg M, Miyachi Y, Bornstein SR. The clinically inapparent adrenal mass: update in diagnosis and management. Endocr Rev 2004;25:309-340

5. Glazer DI, Mayo-Smith WW. Management of incidental adrenal masses: an update. Abdom Radiol (NY) 2019 Jul 29 [Epub]. Available at. https://doi.org/10.1007/s00261-019-02149-2

6. Lenert JT, Barnett CC Jr, Kudelka AP, Sellin RV, Gagel RF, Prieto VG, et al. Evaluation and surgical resection of adrenal masses in patients with a history of extra-adrenal malignancy. Surgery 2001;130:1060-1067

7. Frilling A, Tecklenborg K, Weber F, Kühl H, Müller S, Stamatis G, et al. Importance of adrenal incidentaloma in patients with a history of malignancy. Surgery 2004;136:1289-1296

8. Mayo-Smith WW, Song JH, Boland GL, Francis IR, Israel GM, Mazzaglia PJ, et al. Management of incidental adrenal masses: a white paper of the ACR Incidental Findings Committee. J Am Coll Radiol 2017;14:10381044

9. Park JJ, Park BK, Kim CK. Adrenal imaging for adenoma characterization: imaging features, diagnostic accuracies and differential diagnoses. Br J Radiol 2016;89:20151018

10. Paulsen SD, Nghiem HV, Korobkin M, Caoili EM, Higgins EJ. Changing role of imaging-guided percutaneous biopsy of adrenal masses: evaluation of 50 adrenal biopsies. AJR Am J Roentgenol 2004;182:1033-1037

11. Korobkin M, Giordano TJ, Brodeur FJ, Francis IR, Siegelman ES, Quint LE, et al. Adrenal adenomas: relationship between histologic lipid and CT and MR findings. Radiology 1996;200:743-747

12. Boland GW, Lee MJ, Gazelle GS, Halpern EF, McNicholas MM, Mueller PR. Characterization of adrenal masses using unenhanced CT: an analysis of the CT literature. AJR Am J Roentgenol 1998;171:201-204

13. Elsayes KM, Emad-Eldin S, Morani AC, Jensen CT. Practical approach to adrenal imaging. Radiol Clin North Am 2017;55:279-301

14. Katabathina VS, Flaherty E, Kaza R, Ojili V, Chintapalli KN, Prasad SR. Adrenal collision tumors and their mimics: multimodality imaging findings. Cancer Imaging 2013;13:602-610

15. Untch BR, Shia J, Downey RJ, Carrasquillo JA, Panicek DM, Strong VE. Imaging and management of a small cell lung cancer metastasis/adrenal adenoma collision tumor: a case report and review of the literature. World J Surg Oncol 2014;12:45

16. Mitchell DG, Crovello M, Matteucci T, Petersen RO, Miettinen MM. Benign adrenocortical masses: diagnosis with chemical shift MR imaging. Radiology 1992;185:345-351

17. Korobkin M, Lombardi TJ, Aisen AM, Francis IR, Quint LE, Dunnick NR, et al. Characterization of adrenal masses with chemical shift and gadolinium-enhanced MR imaging. Radiology 1995;197:411-418

18. Mayo-Smith WW, Lee MJ, McNicholas MM, Hahn PF, Boland GW, Saini S. Characterization of adrenal masses $(<5 \mathrm{~cm}$ ) by use of chemical shift MR imaging: observer performance versus quantitative measures. AJR Am J Roentgenol 1995;165:91-95

19. Israel GM, Korobkin M, Wang C, Hecht EN, Krinsky GA. Comparison of unenhanced CT and chemical shift MRI in evaluating lipid-rich adrenal adenomas. AJR Am J Roentgenol 2004;183:215-219

20. Seo JM, Park BK, Park SY, Kim CK. Characterization of lipid-poor adrenal adenoma: chemical-shift MRI and washout CT. AJRAm J Roentgenol 2014;202:1043-1050

21. Haider MA, Ghai S, Jhaveri K, Lockwood G. Chemical shift MR imaging of hyperattenuating (> $10 \mathrm{HU})$ adrenal masses: does it still have a role? Radiology 2004;231:711-716

22. Korobkin M, Brodeur FJ, Francis IR, Quint LE, Dunnick NR, Londy F. CT time-attenuation washout curves of adrenal adenomas and nonadenomas. AJR Am J Roentgenol 1998;170:747-752

23. Terzolo M, Stigliano A, Chiodini I, Loli P, Furlani L, Arnaldi G, et al. AME position statement on adrenal incidentaloma. Eur J Endocrinol 2011;164:851-870

24. Park BK, Kim CK, Kim B. Adrenal incidentaloma detected on triphasic helical CT: evaluation with modified 
relative percentage of enhancement washout values. Br J Radiol 2008;81:526-530

25. Liu T, Sun H, Zhang H, Duan J, Hu Y, Xie S. Distinguishing adrenal adenomas from non-adenomas with multidetector CT: evaluation of percentage washout values at a short time delay triphasic enhanced CT. Br J Radiol 2019;92:20180429

26. Northcutt BG, Raman SP, Long C, Oshmyansky AR, Siegelman SS, Fishman EK, et al. MDCT of adrenal masses: can dual-phase enhancement patterns be used to differentiate adenoma and pheochromocytoma? AJR Am J Roentgenol 2013;201:834-839

27. Barzon L, Sonino N, Fallo F, Palu G, Boscaro M. Prevalence and natural history of adrenal incidentalomas. Eur J Endocrinol 2003;149:273-285

28. Choi YA, Kim CK, Park BK, Kim B. Evaluation of adrenal metastases from renal cell carcinoma and hepatocellular carcinoma: use of delayed contrast-enhanced CT. Radiology 2013;266:514-520

29. Park SY, Park BK, Kim CK. The value of adding (18)F-FDG PET/CT to adrenal protocol CT for characterizing adrenal metastasis ( $\geq 10 \mathrm{~mm}$ ) in oncologic patients. AJR Am J Roentgenol 2014;202:W153-W160

30. Ho LM. Adrenal imaging: a three-category approach to managing incidentalomas. Appl Radiol 2018;47:8-13

31. Allen BC, Francis IR. Adrenal imaging and intervention. Radiol Clin North Am 2015;53:1021-1035

32. Rossi A, Incensati R. Bone tissue in adrenal myelolipoma: a case report. Tumori 1998;84:90-93

33. Song JH, Chaudhry FS, Mayo-Smith WW. The incidental adrenal mass on CT: prevalence of adrenal disease in 1,049 consecutive adrenal masses in patients with no known malignancy. AJR Am J Roentgenol 2008; 190:1163-1168

34. Daneshmand S, Quek ML. Adrenal myelolipoma: diagnosis and management. Urol J 2006;3:71-74

35. Palmer WE, Gerard-McFarland EL, Chew FS. Adrenal myelolipoma. AJR Am J Roentgenol 1991;156:724

36. Taffel M, Haji-Momenian S, Nikolaidis P, Miller FH. Adrenal imaging: a comprehensive review. Radiol Clin North Am 2012;50:219-243

37. Zhang HM, Perrier ND, Grubbs EG, Sircar K, Ye ZX, Lee JE, et al. CT features and quantification of the characteristics of adrenocortical carcinomas on unenhanced and contrast-enhanced studies. Clin Radiol 2012;67: $38-46$

38. Kenney PJ, Wagner BJ, Rao P, Heffess CS. Myelolipoma: CT and pathologic features. Radiology 1998;208: $87-95$

39. Otal P, Escourrou G, Mazerolles C, Janne d'Othee B, Mezghani S, Musso S, et al. Imaging features of uncommon adrenal masses with histopathologic correlation. Radiographics 1999;19:569-581

40. Rozenblit A, Morehouse HT, Amis ES Jr. Cystic adrenal lesions: CT features. Radiology 1996;201:541-548

41. Guo YK, Yang ZG, Li Y, Deng YP, Ma ES, Min PQ, et al. Uncommon adrenal masses: CT and MRI features with histopathologic correlation. Eur J Radiol 2007;62:359-370

42. Udelsman R, Fishman EK. Radiology of the adrenal. Endocrinol Metab Clin North Am 2000;29:27-42

43. Kawashima A, Sandler CM, Ernst RD, Takahashi N, Roubidoux MA, Goldman SM, et al. Imaging of nontraumatic hemorrhage of the adrenal gland. Radiographics 1999;19:949-963

44. Lee JM, Kim MK, Ko SH, Koh JM, Kim BY, Kim SW, et al. Guidelines for the management of adrenal incidentaloma: the Korean Endocrine Society, Committee of Clinical Practice Guidelines. Korean J Med 2017;92:4-16

45. Francis IR. Distinguishing benign from malignant adrenal masses. Cancer Imaging 2003;3:102-110

46. Casola G, Nicolet V, VanSonnenberg E, Withers C, Bretagnolle M, Saba RM, et al. Unsuspected pheochromocytoma: risk of blood-pressure alterations during percutaneous adrenal biopsy. Radiology 1986;159:733735

47. Hagspiel KD. Manifestation of Hodgkin's lymphoma in an adrenal myelolipoma. Eur Radiol 2005;15:17571759

48. Glazer HS, Lee JK, Balfe DM, Mauro MA, Griffith R, Sagel SS. Non-Hodgkin lymphoma: computed tomographic demonstration of unusual extranodal involvement. Radiology 1983;149:211-217

49. Rha SE, Byun JY, Jung SE, Chun HJ, Lee HG, Lee JM. Neurogenic tumors in the abdomen: tumor types and imaging characteristics. Radiographics 2003;23:29-43

50. Szolar DH, Korobkin M, Reittner P, Berghold A, Bauernhofer T, Trummer H, et al. Adrenocortical carcinomas and adrenal pheochromocytomas: mass and enhancement loss evaluation at delayed contrast-enhanced CT. Radiology 2005;234:479-485

51. Park BK, Kim B, Ko K, Jeong SY, Kwon GY. Adrenal masses falsely diagnosed as adenomas on unenhanced and delayed contrast-enhanced computed tomography: pathological correlation. Eur Radiol 2006;16:642-647 
52. Yoon JK, Remer EM, Herts BR. Incidental pheochromocytoma mimicking adrenal adenoma because of rapid contrast enhancement loss. AJR Am J Roentgenol 2006;187:1309-1311

53. Park SY, Park BK. Adrenal gland and retroperitoneum. In Korean Society of Urogenital Radiology, eds. Urogenital Radiology-Urogenital Imaging. 2nd ed. Seoul: Ilchokak 2019:250-269

54. Wajchenberg BL, Albergaria Pereira MA, Medonca BB, Latronico AC, Campos Carneiro P, Alves VA, et al. Adrenocortical carcinoma: clinical and laboratory observations. Cancer 2000;88:711-736

55. Ng L, Libertino JM. Adrenocortical carcinoma: diagnosis, evaluation and treatment. J Urol 2003;69:5-11

56. Bharwani N, Rockall AG, Sahdev A, Gueorguiev M, Drake W, Grossman AB, et al. Adrenocortical carcinoma: the range of appearances on CT and MRI. AJR Am J Roentgenol 2011;196:W706-W714

57. Korivi BR, Elsayes KM, De Castro SF, Garg N, Qayyum A. An update of practical CT adrenal imaging: what physicians need to know. Curr Radiol Rep 2015;3:12

\section{부신우연종: 영상의학적 접근과 감별진단}

이명석*·문민환·성창규

부신우연종(adrenal incidentaloma)은 부신 질환을 의심할 만한 임상증상 없이, 다른 이유 로 시행한 영상검사에서 우연히 발견된 $1 \mathrm{~cm}$ 이상의 부신 종괴를 의미한다. 내분비 기능이 없는 부신우연종에서 영상의학적 검사의 목적은 양성과 악성을 감별하여 치료 방침의 수립 에 도움을 주는 것이며, 특히 부신우연종의 $80 \%$ 이상을 차지하는 부신선종을 감별하는 것이 중요하다. 본 종설에서는, 이전에 발표된 연구 및 권고안들을 근거로 하여 부신우연종의 영 상의학적 접근방법을 기술하고, 대표적인 종괴의 영상 소견을 기술하고자 한다.

서울특별시 보라매병원 영상의학과 